\title{
Ethics and Law: Reassessment on the Legal Positivism
}

\author{
Mehmet Tevfik Ozcan \\ Istanbul University
}

\begin{abstract}
Legal system in a modern society is administered by judiciary which is due to separation of powers in a constitutional government whose role is congruent with market-based (i.e., capitalist) social formation. At the outset of modernity, an overall morality, as a social system, lacked for ordering all social relations in modern society under overdetermination of market relationships and class differentiation. Despite the fact that we may attribute moral property to the patterned relationship, there is somewhat a common character between morals and laws that both of them visibly set forth by reciprocity between individuals and social groups, which are backed by external sanctions as manifested with notion of justice, as evaluative criterion of impartiality. Thereby, the other problem is a tiny relationship or sometimes tension between social systems of morals and individual ethical virtues; even though some philosophers are willing to equate virtues, morals, and the law as squarely reducing virtues to obey the established law. As though, legal system and some morals incidentally coincide, the law cannot be evenly rely on morality in spite of presumed legitimacy by means of morals that have been overall subject matter of philosophy of law. Regarding the social structure of any capitalist society, I frankly say that law autonomously or semi-autonomously arose as a discrete depolitical power system other than system of morals which was ultimately determined by mode of production. Therefore, it relies on a convention-like social approbation, whatsoever is stably or unstably balanced with political power.
\end{abstract}

Keywords: law, morality, ethics, legal positivism, depolitical

\section{Introduction}

Contemporary legal studies reluctantly reveal a dilemma between the dominant ideology of law and actual working of legal systems which ostensibly disdain paternalism, but there is any ground for favored liberalism that is generated by damned presence of monopoly capitalism and mass society. Despite there are strictest numbers of criticisms which urge on total negation of very premises of liberal legal ideology, the overall liberal ideologies or discourses rely on some moral bearings taken for granted in order to formulate legitimacy of law through ethical action of anticipated free individual, but it is almost entirely absent. The fact that liberalism has already demolished traditional liaison between law and morals is what constricted ethical action of individual with legally defined bonds of human conduct, likely-looking in legal positivism, in spite of tackle with traits of ethical actions which might be manifested in welthanschauungs of individuals. Albeit an overall morality was displaced by capitalism, a great number of legal scholars are still preaching moral obeisance to law without questioning how an ethical theory is compromising on that obedience that they reluctantly jettison conceptual individual of liberalism via reawakening paternalist conception of obedience.

Mehmet Tevfik Ozcan, professor, Faculty of Law, Istanbul University, Turkey; main research fields: the Rule of Law, Legal Positivism, Ideology of Law, and Globalization. E-mail: mtozcan@istanbul.edu.tr. 
Although, the diversity of ethics, morality, and law is congenial to any capitalist society, a great number of theorists on morality are eager to think about them in convergence, despite some tensions may be originated therefrom. Firstly, such theorists avowedly entangle ethics and morals anyhow reckoning them identical, disregarding substantive difference between deliberation of individual human being and obligatory nature of social conduct. The former is a question of individual conscience and action, whereas the latter is embodiment of a social mechanism which functions as a constraint in order to curb freedom of will (i.e., the core idea of ethics). Secondly, law is a diverse social mechanism other than moral that is embarked on by organized depolitical power in any political society, but, additional to its assigned role, it straightforwardly impacts upon the dominant system of morals. In this milieu, there are tumultuous debates that consequentially preach moral duty to obey established legal order, which still relies on marketplace pattern, without any questioning on merit or demerit of its consequences from humanitarian point of view. In this paper, my aim is to demonstrate groundless positioning of the idea which preaches moral obligation to obey law tout court, without any questioning on inclusiveness and legitimacy of morals. Firstly I briefly try to settle the problem of morals with reference of the Kantian and Humean moral theories. Secondly, I will endeavor to point the diversity between morals and ethics, and lastly I will point out legal positivism that interprets the law as an all-inclusive sub-system of society, and depolitical power system in a constitutional government without any recourse to moral legitimacy.

\section{Debated Contents of Ethics and Morality: The Moral Ideas of Kant and Hume}

To trace a triangular relationship among law, ethics, and morality is a very confusing conjecture and domains of law and morality are generally debated on the ground of social benevolence taken for granted, regardless of interest-based nature of the two domains in a capitalist society. Philosophers and lawyers generally have very strong inclination to presume that moral values on humane point of view can be instilled by way of negotiation between the human individuals. To the extent that we debate about those crucial domains, we must ponder on diverse individual and social spaces, albeit the enlightenment rationalism was incognizant. Besides, this confusion has been overburdened by the two main traditions of moral theory which might be roughly summed up under the headings of rationalist moral theory and happiness morality since early epochs of history of philosophy. Contrariwise, contemporary anthropology and related social sciences have been in a great achievement to explain culture including morality therein; the scientists scrutinize morality as a subject of empirical research with surpassing philosophical interpretation and enunciation. In this context, if we credit the value of scientific knowledge to some extent, we are under obligation to take part some scientific paradigms or traditions of research in social sciences by way of withdrawing morals from the topics of philosophy.

By and large, morality comprises multifarious human deeds and valuations whose core ideas essentially dictate good conduct and define the scope for human freedom through endorsing duty and obligation unto individual on behalf of other individuals, social aggregations, and natural environment. Duty is a key conception which embodies moral good and attributed human virtue that attaches both the self-control (negative aspect) and deliberative action (positive aspect) on the merits of its responsibility and ethical personality schemes. In this context, both aspects of duty are aiming to engender ethical action, whether or not coupled with legal domain. Despite Immanuel Kant gripped the rationalist outlook which might be very open to criticisms, he minutely diversified the moral law and ethics, as postulated in dyadic relations of civil state and personal individual. Kant is probably the most crucial philosopher upon morality and though his ideas cannot 
be hastily partaken and is far from open texture for a comprehensive interpretation, he puts forward an exclusive basement for criticism on law and morals. Kant began with good will conception in his The Moral Law $^{1}$ where he designated "the moral law" conception was good in itself, because it relied on reason, and corollary of what was assumed as necessary (Kant 1898, 8). Apart from usual meaning of the word, Kant marks "the will" as a notion which is denoting highest practical reason, presumably exists in the sound natural understanding of individual, and is a priori practical reason as collateral to the categories pure reason. To the extent that it is concerned with the practical reason, as is pointed in Kantian doctrine of virtue, it legislates duty as an end that determines the maxim in its formal existence and should create a posteriori forms of duty as actual embodiment of analytical proposition (Kant 1898,16). The will and reason concepts are identical in Kantian system and this identity embodies a priori "the moral law" and categorical imperative, which is apodictic in itself. Kant's famous formula traces formal property of only one categorical imperative: "Act only on that maxim whereby thou canst at the same time will that it should become a universal law" (Kant 1898, $38)^{2}$ According to the Kantian outlook, categorical imperative denotes freedom of all, that is why all rational creatures, embody the right, as the universal law:

Thus the universal law of Right [Rechtgesetz], so act externally that the free use of your choice can coexist with freedom of everyone in accordance with a universal law, is indeed a law [gesetz], which lays an obligation on me, but it does not at all expect, far less demand, that I myself should limit my freedom to those conditions just for the sake of this obligation; instead, reason says only that freedom is limited to those conditions in conformity with the idea of it and that it may also be actively [tätlich] limited by others; and it says this as a postulate that is incapable of further proof. (Kant 1991, 56-57)

The Kantian moral law is enunciation of the law in general in its formal aspect and we plainly apprehend that Kant exalted it as supreme legislation, even though it is assumedly as related to morals. Regarding to the Kantian conception of law, in general, insofar as it is being considered within limits of positive law, it comprises all purview of the liberal conception of law, because its outcomes are very like the elementary constituents of liberal ideology which are mainly life, liberty, private property, night watchman state, and the rule of law (Kant 1887), but his political position should not be considered as liberal any more, neither, he seems very sympathetic to conservatism. Hence, he gloomily sanctified legislation, to some extent obnoxious to the liberal paradigm of legal order, wherein he equalized the law with a law (gesetz) which emanated from legislature that was glorified with identifying as "pure practical reason":

Every state contains three authorities within it, that is, the general united will consists of three persons (trias politica): the sovereign authority [Herrschergewalt] (sovereignty) in the person of legislator; the executive authority in the person of ruler (in conformity to law) and judicial authority (to award to each what is his in accordance with the law) in the person of the judge (potestas legislatoria, rectoria et iudicaria). (Kant 1991, 125)

It must be taken seriously that his ideas should be considered as inextricably entangled with the contemporaneous Prussian enlightened absolutism and its coercive modernization scheme, which equated law and statute under shade of the Prussian codification scheme that it yielded to Allgemeines Landrecht für die Preußischen Staaten in 1794.

The Kantian categorical imperative is akin to categories of pure reason where formal property of duty is congenial to the world of noumenon but infallibly relates with knowledge about phenomenon that brings about the construed hypothetical imperative in relation with experimentation. Kantian categorical imperative is aiming to an end for objectivity of law whose motivation is the good will and practical reason which are 
presumably converge on freedom of will. Meanwhile, subjective counterpart of categorical imperative is maxim, which denotes the principle under guidance of the objective law on which human being is capable to act, even if he might have been ignorant of or living in conditions of natural inclinations (Kant 1898, 38); in which "subjective" finds its meaning within "objective." Kant pointed: "Act always such a maxim as thou canst at the same time will to be universal law; this is the sole condition under which a will can never contradict itself; and such an imperative is categorical...." (Kant 1898, 55). Kant diversified the moral law from morality and the former corresponded to mundus intelligibilis whereas the latter to some extent was nourished by mundus sensibilis, which has got anthropological value and comprised empirical element. Kant expressed that morality should be guided by the moral law, but morals per se rely on empirical principles which are, in Kantian terms, yielded from the sensations and accumulated experiences whereby their nature were conditional and synthetic (Kant 1898, 62-64; 105; 1991, 45). Hence, morality can be founded on heteronomy whose causation is purposive for happiness but not aims the rational end.

It seems that Kant did not displace his contemporaneous conception of morality, but preferred to form an analytical basement for the law by means of the so-called "moral law." The "morality" conception of the age was, at any rate, expressed by David Hume (1896, 455 et seq.) as emotional conception rooted in pain and pleasure dichotomy which was accentuated in III.ii.1 section of A Treatise of Human Nature, whereby moral good could not rely on reason and therefore was not capable of demonstration. Hume expressed in III.i.2 that affections and understanding are of distinct domains of human beings, therefore he said that the former without direction of latter incapacitate human being. To the extent that affections are solely insufficient for social state and liberty, they need inter-individual experience, but moral precepts cannot be derived from reason, because, as is alleged in II.iii.3 (Hume 1896, 423 et seq), the reason alone can never be a motive to any action of the will and can never oppose passion in the direction of the will. The overall conception of morality (not the moral law) in the Kantian point of view is likely inherited from Humean conception of morals, which are driven by pursuit of happiness, nevertheless have hypothetical character. Contrary to Hume, Kant believed that "practical and speculative reasons are based on same faculty, insofar as both of them rooted in the pure reason" (Kant 1898, 182). Consequently, Kant set forth identity between pure and practical reasons, wherein precepts of the moral law have analytic property, i.e., major premise, from which other premises can be inferred, parallel to logical inferences.

A comparison between the moral theories of Kant and Hume seems a bit obsolete to someone, but such comparison may highlight the debate on compliance of individual to the established legal order. Both of them sanctified conservative point of views, when they eulogized the present legal order. Kant focused on formalness of law without any further explication or examining legal coding that he disregarded the difference between political nature of legislation and mode of its entrenchment in the body of legal system, and indiscriminately obliged everyone to obey all legislation. Kant's starting point is private rights, as preliminary step for explaining legal order that its quintessence is private possession of external objects, which determines possession of mine and thine thereof, by which all system of rights and duties are articulated (Kant 1991, 68). Despite the fact that Kant radically differed from Hume's sensitivism in moral theory with postulating rational human being in the moral law doctrine, both of them would be similar as regards their conservatism in legal and political domains. By the way, Hume was hinged on the doctrine of virtues for reasonable basement of the law, whereas Kant thought that virtues should have been ultimately determined by the moral law(Hume 1896, 490-492). In fact, the Humean doctrine of virtue incorrigibly relied on self-love and egoism of individuals (i.e., 
property owners) in III.ii chapter of his above-mentioned book, in which justice was artificially established by way of their convention.

Lastly, I must point out virtue, as subjective aspect of morality, may squarely belong to solitary individual, which was interpreted in doctrine of virtues. Virtue is a crucial problem to some extent encompassing duty, social approval, and deliberation that would evoke ethical deliberation or obstruct it with a blind obligation to external duty. Contrary to the ancient vis-à-vis parallelism between morality and ethics, Kant diversified domains of the moral law and ethics of individual (Kant 1991,185); hence ethics was placed under doctrine of virtues which should be stemmed from the moral law. When Kant traced diversity between objectivity and subjectivity or noumenon and phenomenon (Kant 1991, 199), they also conformed to the methodological diversity between analytic and synthetic propositions, by which the internal aspect (i.e., virtue as duty) should be subjected to the external (i.e., the objective law). According to Kant, supreme principle of right is the moral law which has analytic property, conducting to the categorical imperative, wherein ethical duty should embody maxim, but there is not an analytical necessity for conforming to that categorical imperative. The conformity, as such, is an exhortation for becoming a virtuous person in guidance of the moral law. Kant enunciated two kinds of duties, which were purposive for one's own perfection and happiness of others and attainment of those purposes concerns us with hypothetical imperative, as is traced by him, "accordingly the hypothetical imperative only says that the action is good for some purpose, possible or actual. In the first case it is a problematical, in the second an assertorial practical principle" (Kant 1898, 39-40). Therefore, the Kantian doctrine of virtue per se sets forth a hypothetical property that denotes moral strength of "a man's will," which might be embodied in human condition, whether or not the moral law (i.e., the objective end) is existent, thereon ethical personality would act upon a maxim and be purposive for the two duties (Kant 1991, 206-210). Kant normally postulates civic life under guidance of the moral law or, otherwise, lack of the moral law is only a presumption (Kant 1991, 231; 1898, 62-65; 105). Thus, according to the Kantian idea, the maxim of ethical duty should be guided by categorical imperative of the moral law; in other words, virtue rationally ends duty by way of obedience to the moral law.

The Humean's point of view on virtue was consistent with his diversification between reason and passion which unravels non-rational sources of the will (Hume 1896, 413-418). While, Kant entangled reason for determining the will, he promoted action as a kind of logical inference because of considering its maxim as a proposition $^{3}$ (Kant 1991, 52; 1898, 184). Beforehand, Hume demarcated domains of reason and passions when he expressed that "The approbation of moral qualities most certainly is not deriv'd from reason, or any comparison of ideas; but proceeds entirely from moral taste, and from certain sentiments of pleasure or disgust, which arise upon the contemplation and view of particular qualities and characters" (Hume 1896, 581). By the same token, Hume uttered the distinction between virtue and vice, but he considered that both of them emanated from pleasure and pain, and that induced us to favor happiness, by which the two principles emerge in social sphere that they are firstly sympathy and communication of sentiments, and secondly making comparison between sentiments, which might entirely diverge as regards to persons and situations, in spite of their intrinsic values (Hume 1896, 592-594). Hume epistemologically denied the role of reason on morals, but he gently inclined deliberation by way of reason after experience of external impulsions.

The Kantian and Humean theories on morals disclose us an upside down mental image when referring one by means of another that are significant only in their different starting points and ultimate considerations. Hume grounded on morality through plurality of individuals who have emotions and can accomplish virtue through 
communication, whereas Kant postulated objectivity of the moral law and that ethical virtue is fulfilled in terms of obligation which was embodied in individual achievement in pursuance of the moral law. The two points of view may correspond with the two types of state of minds that they correspond with the two different modernities, namely, British liberalism and Prussian etatism. The climax of the Humean ethics is manifested itself in glorification of egoist individual, regarding his ideas on justice and possession (Hume 1896, 486 et seq.), but sympathy and communication bestow a salient way in order to mitigate vicissitudes, conflicts, and unsocial consequences in conducts of solitary individuals, by which egoism of individuals could be reconciled. Hume alleged that there was only remedy for justice to form a human convention which is somehow engendered from human artifice, named as virtue of public justice, surpassing action of solitary individual for justice. According to Hume, self-interest is only motive to establish virtue of individual justice, but public justice can be achieved by ways of sympathy and public interest (i.e., peace and security), which are moral approbations, established in progress of human beings (Hume 1896, 499 et seq.). In this nexus, Hume, on the one hand glorifies natural individual with his self-love and interests as stable properties of soul, on the other hand acknowledges progression and malleability of impressions that engender justice by way of sympathy and convention.

Hume explained such shift with regarding to the volume and breadth of society, in spite of the Lockean point of view, which avowedly rely on state of nature, natural rights, and forming a political society in order to secure life, liberty, and property (Locke 1966, 154-164). For Hume, there was no state of nature, so there were no inborn morals or rights, hence natural condition is a kind of presumption of poets, very like that in the "Golden Ages" poem (Hume 1896, 493). Hume confined himself to an idea that society increased through more numerous members to become tribe and nation, very parallel with increasing trade and other promises. Initially human beings were considered under threat of violation with their natural virtues (interests), because the solitary individual cannot peacefully redress such encroachments. Even though the injustices are so remote and do not infringe us, we still consider them vicious, because they are felt pernicious to all society and uneasiness for every single individual. In this context, Hume pointed that the problem of justice was felt as a public concern, for which we needed convention by way of sympathy, not as being inferred from an analytical category, but as a consequence of human experimentation through impressions (Hume 1896, 499). The government therefore took part of this virtue, because it was generated from public interest, by which our individual senses of justice extended over their natural bonds that were gradually subjected to public praise, i.e., the cause of our esteem to justice, thereby new generations are born and educated in a social milieu where its participants respect public justice.

\section{Morality and Ethics are not Necessarily Parallel}

Owing to the contemporary development in humanities, especially in cultural studies and social anthropology, the Kantian and Humean's point of views sufficiently reveal that the philosophies on morals are not fully plausible for clarifying the very nature of social mechanism of human conduct. As aforesaid, Kant consciously withdrew himself from social reality and his theory on the moral law is only concerned with the mundus intelligibilis; whereas the Humean's point of view stemmed from phenomenal world, but cannot astutely provide robust approval of the established legal order. However, both of them presumed a single and unified morality, despite there are no seamless moral systems in modern societies, in which only miscellaneous moral environments reside. Communitarian morals or theories of virtue ethics are conscious of the problem, but 
in my opinion, they cannot generally provide any remedy for a reliable theoretical solution. As having been depended on a comprehensive tradition since Cicero (2004), any initiation to rely on rationality in a moral theory inherently inclines to postulate immutable moral goods, heretofore the rationalist philosophers on morals reaffirm their metaphysical truisms whatsoever meticulously associated with deity or not. Kant moderately pursued this path with only one exception, in which his categorical imperative proposes a form, not a substantive moral code, whereas his consideration of virtue should have been construed as embodiment of the maxim in guidance of the moral law. But in practice, it was acquiescence of supreme will of the sovereign in legal form. Conversely, the Humean morals and virtue theory, at the first sight, focused on overall public opinion as convention which was assumedly a sum total of individual sensations, it is therefore theoretically liable to some fluctuations in ethical convictions. Furthermore, that convention had an important defect, both because propertiless people have been consequentially reckoned irrelevant to the virtue, and because consent engineering role of the sovereign power was consciously concealed. As a student, I do not aim to confer about a pure moral theory, but my concern is to insist on diversity between morals and law, even though there are some borderline features or similarities between them. Niklas Luhmann (2004), German legal sociologist, diversified code and programme in his system theory of law. The former, as binary coding, denoted nexus of articulation of legal provisions and judgements in legal sub-system of society, whereas the latter designated the facts and ideas emanated from environment of legal system but might possibly integrate into the system by means of coding. In this context, customs, morals, and claims for justice have been deemed within programme which might be possibly selected and coded in order to entrench legal system. Morality is an indefinite conception that indiscriminately encompasses all social manners and customs which are actually or potentially backed by social sanctions. The question can be posed if there is a pure morality or pure ethics that can be separately investigated, as far as we discuss similar problems in jurisprudence for the sake of the "pure" theory of law. Morality is a research subject for social sciences in the contemporary world, though some number of philosophers still interpret it as a problem of philosophy. Meanwhile, ethics is still a topic of philosophy, where philosophers enunciate within conscious and deliberative action; thereby ethical action must be minutely diversified from instinctive behavior and interest articulation. Instincts and interests generally instigate conflicts, even though they are eventually mitigated by bargaining, reciprocity, and balancing of interests under the aegis of shared morals or other norms. Even if we presume unanimity and convention as short cut presumptions on morals, they are not vis-à-vis identical with ethics, because they only designate social order, not individual conduct.

Morals impose unilateral or bilateral obligations which are furnished with sanctions to some extent either aroused from public disapproval and social ostracism or stirred by individual retribution in all forms of reciprocity, whatever mitigate or manage conflicts on the grounds of prevalent state of mind. In this respect we presume society via communication between individuals and groups. As Marshal Sahlins pointed out, the three forms of reciprocity master it and they are, namely, "generalized," "balanced," and "negative" forms of reciprocity (Sahlins 1968, 85). ${ }^{4}$ Morals are similarly functioning with law, but either may adjust to social balance which is overdetermined by law or resist it, whatsoever they are brought about by entire structuration of status quo. Morals are essential constituents of culture that have inner relations with all traits of social life, especially the state of mind, balance of powers, and relations of production that manifest some systems of social norms in a complex society. As regards the scientific studies on modernity, capitalism melted overall morality and concomitant state of mind in society, and anyhow reduced it to balanced reciprocity of market 
relations, in which human beings can hardly ever anticipate any "generalized" reciprocity. Karl Marx expressed in his criticism on commodity fetishism that all social relations were magically translated to the market relations of commodity owners in capitalist society; thereafter transaction of exchange values concealed all human relationships (Marx 1909, 81 et seq.). Apart from their paradigmatic assumptions were visibly different from Marx, Max Weber and Richard Henry Tawney alleged that capitalism dismantled the established morality. Weber (2001) construed a relationship between capitalist development and new type of virtue in the Protestant communities, especially in Calvinism, and they upheld religious asceticism, frugal living, and daily discipline of work with sanctifying middle-class economic acquisition through denunciation of the moral economy of Roman Catholicism. Weber sanctified his fictitious "spirit" of capitalism, but he sorrowed that the supposed spirit of capitalism dramatically faded away after the early epoch of capitalism as a consequence of enrichment, whereby that spirit converted to covetousness (Weber 2001, 123-125). Weber meant that the spirit of capitalism dismantled traditional morality on behalf of rationalization, but afterwards yielded with a moral vacuum. Similarly, Tawney, who was a more placid theorist on the relationship between Puritanism and capitalism, pointed out that Puritanism was not genealogy of capitalism, but only tonic which braced its energies. Tawney qualified capitalist society as likely to a joint-stock company, thereupon rights and liabilities of its shareholders are strictly limited, that is why there is no space for a beneficent morality but only economic interests (Tawney 1963, 164). In this milieu, Tawney worded that human beings in capitalist society are like a squirrel in a revolving cage, because capitalists who can hardly take care of ethical virtues of benevolence concentrate on greedy accumulation (Tawney 1920, 2-3). In the same way, we must add that there is no room for benevolence among laborers, except among members of some permanent circles and unions, because they can hardly earn their livelihood and cannot acquire economic surplus.

The appraisals on the Protestant ethics revealed that morals may not immediately determine ethics, therefore there may be some personal virtues even a very deep-rooted moral abatement or permanent vacuum of morality. The idea on diversity between morality and ethics was deep rooted in the German enlightenment in 18th century; nourished in Lutheranism and Pietism in theology studies, and especially triggered by the Halle University to cope with a rationalist ethics via divorcing from established morals (La Vopa 2002, 137-196). Although zero degree of morality is probably a hypothesis for any comprehensive society, there are some existing moral rules which are intact or reshaped in smaller social groups or communities, but there cannot be outright morals which are capable of to embrace totality of any capitalist society. Therefore I frankly say that a seamless morality in any modern society is non-existent and it may be only denoted to a society taken for granted and like Kant's presumption on mundus intelligibilis. All civilized societies, especially under capitalist mode of production, are segmental, where horizontal (e.g., communities) and vertical (viz., status groups, social classes, or all forms of stratification) categories reside, so comprehensive morality for any capitalist society may be only a proclamation of dominant moral outlook, which is approved by dominant classes in the established balance of power. Subsequently, the alleged congruence between law and morality may be meaningful only when we consciously disregard alternate moralities. Hence, allegation for prima facia moral obligation to obey law is unpromising endeavor that means circularity of a chicken and egg situation, because one facet of power system (i.e., the law) is specified with reference to the other, viz., dominant morals (cf., Christie 1990).

Apart from those ideas, I achieve for an ethical posture in my personal life, like any other responsive individuals. First of all, I must ponder that there is any all inclusive morality that is able to master life of society 
in the age of global capitalism, because the common morality of all societies was already faded away. Notwithstanding a common morality is absent, I am still longing for virtuous life where all responsive human beings have to act with benevolence on behalf of humanity. There is no a plausible moral code or commonly shared morality in our societies or in globe, but virtue is possible and wishful for human individual with due regard to human dignity and the freedom of will. Ethics and morals are not necessarily identical; anyhow human virtue cannot be reduced to a certain morality, owing to Weber's appraisal on the Protestant ethics. Therefore, ethics is a domain of self-respect, integrity of individual, and benevolence, whatever relies on personality ideal of individual in any social milieu which may or may not be engendered by any custom, religious belief, or secular ideology. In the same way, virtues can be traced with or without reference to any moral code, laws, religious belief, or purview conception of civic life, as is coined by the existentialist philosophers that they may be an outcome of individual breed, experimentation, and value orientation.

Regarding to the Kantian's view, the moral law and maxim were respectively due to the domains of objectivity and subjectivity, despite the virtue of ethics (i.e., acting according to a maxim) should be acted according to the categorical imperative of the moral law. A virtue is a personal positioning of individual who unilaterally performs it as self-imposing duty, which attunes his conscience according to his inner freedom and deliberation. Owing to the conceptualization of Leon Petraziycki, who was Polish origin Russian legal philosopher at the outset of 20th century, pointed out in a dissimilar context that "imperative" and "attribution" may divide domains of ethics, morals, and law (Petraziycki 2011, 45). I borrow the two conceptions from Petraziycki, but I construe them according to my point of view, by which "imperative" may denote inclusively how law and morals are furnished with external sanctions that they refer outer constraints on individuals, whereas "attribution" should be judged on its merits which may specify virtues of individual as self-imposition of a duty somehow is determined by his inner freedom. This diversification may reveal to us the domain of autonomy, reflection, and deliberation, which demarcates virtuous conduct from flattering to any societal force or coercive submission to the external rules, legal or moral. Kantian or Humean ideas consequentially restrict virtue with allegiance to the established legal order but, in practice, an individual may infrequently attribute himself an ingenious virtue as a duty to disobey the rules or commands of sovereign, so he may negate them considering unjust or pernicious, thereby the issue at hand may arouse him for opposition or revolution.

There is still a question posed about what extent may be the scope of deliberation of solitary individual. Virtue can only be presumed with reference to vice, like all linguistic phenomena; anyway meaning is constructed by way of binary oppositions within social convention. Virtue and vice traditionally denoted certain criteria and they might be eventually formed under shadow of social approval and disapproval. My point is that ethical action is more than a fame or social approbation and ethics would not been plainly reducible to blind subjection to any social conviction. As is inherited from heroic age of Greeks, the meaning of the concept of virtue (arete) had been liable to important modifications (MacIntyre 2007, 127), to which philosophers attribute multiple properties, like breed, courage, temperance, education, prudence, justice, and so on. But virtuous conduct can be valued according to the ethical person and social context of his action. Therefore, any abstraction cannot lonely specify ethical action and there is not a ubiquitous worth of any conduct via disregarding its nexus. In this milieu, "good will" can be essential criterion, even though its content and fittingness cannot be predetermined.

Great majority of the moral theories about ethical deliberation have very roots in the pre-modern ages and at any rate, they assume to explain all human conducts and inter-individual relationships within a consistent 
narrative. By the way, we cannot label some sorts of the behavior under the heading of "ethical," especially when they generated from natural instincts or interest articulation. Therefore, I think, contrary to the overall considerations, compromise and justice would not be deemed "ethical," because they entangled with interest articulation and maintenance of a status quo that have no or little relevance to benevolence. Conversely, I consider that ethical action should accomplish benevolence, whether or not someone adhere an ethical explanation of any theory of morals. Ethical action can be specified by devotion for others, thereby the actor ascribes inner restriction to himself in guidance of a certain principle or set of principles, perhaps the principles such as slightly resemble the Kantian maxim, but without sharing his underlying credo. Corollary of this idea is to assume that an ethical action is not commensurable and should not be exclusively hinged on a normative code. That is what, apart from other arguments; ethics radically differs from law and morals, because not only its domain is rigorously personal, but also it may emanate from inner legislation of individual. Consequently, virtue is per se capacity for deliberative action; by which human being can autonomously act in probity (integrity), according to his capability under guidance of his mental state to the degree that he could establish for himself.

\section{Inevitability of Positive Law or How Far Positivism?}

I must begin with my candid opinion that debates on legal positivism can only reflect inclinations of lawyers and legal philosophers, but the legal system of a country is not established according to their will. Legal system is (and was) a consequence of constitution of any political society, on which we presume under a sovereign state notion within the world system. According to Thomas Hobbes, the word "positive" denotes either to mark somewhat in nature or connote something feigned in human mind, but regarded as natural (Hobbes 1998, 25). Therefore, it is apt to think that positive laws are presumed to be feigned like certainty of natural facts. The debate among lawyers cannot determine probable fate of constitutional system and they can only argue about philosophical bearings of judicial discretion, whereon they partially take effect on strict domains of the legal system, comparing with its comprehensiveness. Positive laws and organization of judiciary are not choices of lawyers that had been already settled down by sovereign state as politico-legal outcome of its constitution. Therefore, it seems to me that if someone entitles himself as "legal positivist" or not, it is meaningless for legal scholar and furthermore when we study law per se as a dogmatic system or criticize it, anyhow it has no or little effect upon the system.

Since early times of the legal development, there has been some number of positive laws, whereby we can hastily point to the Roman law, as our common source in scientific study on law. As having been set forth in the Institutes I.ii, ius civile comprised written and unwritten laws and the former included statutes, the plebisicta, the decrees of the senate, the decisions of emperors, edicts of praetors, and answers of jurisconsults, whereas unwritten laws embraced the confirmed usages and customs of the Rome that were resembled as laws and observed long time by the consent of those who employ them. It is no doubt, the Roman ius civile signifies "positive law" (Thibaut 1855, 10), which is not unprecedented, as is pointed in the same section, whereby it referred Athenians who had designated their laws as "ius civile." In this context, we can say that all legal rules in action constitute a positive law system. For example, Constitutio Tanta in Codex I.xvii ordered mechanical application of the Digest in actions without any alteration when it aimed to maintain positive laws; therewith such alteration might have relied on ignorance or be taken place by way of new initiations of lawyers in order to epitomize or summarize legal provisions. Therefore Roman judges were nominated as incumbent on 
practicing the positive law system, without modification by way of interpretation or another way apropos to legal positivism's assumed notification to the lawyers.

As aforesaid, custom has been recognized as a source in the Roman law, but it is a mischievous idea to expect that custom and morals are squarely sources of law in a contemporary society. The fact that customs or mores (viz., morals) had had symbolic value in the Roman world did not denote historical stream of Roman civic culture and nobility, as an ideological symbol of conservatism any more. The Laws of Twelve Tables were promulgated by patrician elites between 451-449 BC, which was ideologically justified as the custom of ancestors, but formulated by way of illustrating Solon's legislation in Athens (Scott 1932). In the same way, the common law system in England was generally assumed as customary law which was strenuously alleged as symbol of the nationwide unification of English law after Henry II (McIlwain 1917). Notwithstanding it reflected English legal system with its peculiar character, other than general rest of the Continental European legal systems, Henry II achieved to centralize judiciary the first time in Europe, by means of case law and precedent, but not by custom, as it was manifested in the prominent old law books like Fleta and Britton, or legal practice of famous lawyers like Ranulph de Glanville and Henry de Bracton (Stopford 1907). Some legal documents of the middle ages were designated as collection of customs, by which we can exemplify Glanville's book, Sachsenspiegel or Cotumes de Beauvaisis. They were more like the collections of cases other than the brute customs or morals of the land that were exclusively addressed to judiciary, bailiffs, or other law enforcement officials (Thatcher and Holmes, eds., 1905, 391-399; Beaumanoir 1899). Anyway, the established metaphor between law and customs might be understandable in pre-modern societies and their states of mind, but it cannot designate any legal system after modernity. In fact, Herbert Lionel Adolphus Hart alleged that custom still was a subordinate source of law in a modern society, but, contrariwise, it may be true if we confine ourselves to commercial customs or new lex mercatioria, except in some coincidences morals and customs overlap with law (Hart 1965, 44). Conversely, as was pointed by Samuel C. Damren (2000), stare decisis or statutes, in general, can change customs, by which we are able to conclude that the law plays decisive role on morals and customs.

As a question of legal profession, legal positivism is in achievement to determine limits and methodology of jurisprudence, especially corresponding with science-based perception of contemporaneous culture, in which we treat legal system not only as elaborate apparatus of social order, but also main stake of communication in civic life. As Gearld J. Postema indicated, practice of law must be familiar to the reasoning or rationality of general public, even though the "reasoning" concept is seriously problematic. Postema (2005) referred three main concerns of legal positivism that might be divided as: (1) limited domain thesis; (2) pre-emption thesis; and (3) sources thesis. The limited domain and sources theses pertain to autonomy of law, its exclusive sources, and methodology, but the pre-emption thesis is partially questionable, because it depends on a presumption about rational society, thereby the law presumably channels adjustment of individuals to the legal system. But, neither society nor legal practice can be exclusively held in logical consistency, because they are bridled by conflicting interests and multiple judgements of lawyers.

Apart from criticisms on the problem, legal positivism matches with dominant ideas and constitutional form of the time that can be considered as summed professional attitude which is posed by judiciary. John Austin, who is probably the most cited legal positivist, tried to demarcate province of jurisprudence, but his outlook may be comprehensible by way of his surrounding ideas which relied on the classical essays of German legal positivism of the 19th century, even so, he might be plainly considered as a British adherent of the 
German legal culture (Schwarz 1934). At the outset, Austin delimited his scope of jurisprudential concern in the first lecture where all legal rules were set by political superiors, which contained commands, imposed duties and should be obeyed by all citizens (Austin 1873, 88-106). By the same token, commands and duties were assumed as correlates that were backed by negative sanctions, both as threats and action. Austin diversified four types of laws which plainly encompassed all norms, among which he enumerated that: (1) the laws of God; (2) positive morality; (3) laws in figurative sense; and (4) positive laws. According to the prevalent idea, contemporaneous with Austin, only positive laws were backed by physical sanctions which were promulgated by men for men, therefore they were capable to be subject-matter of jurisprudence. As was stated by Austin, the laws of God might function to impede criminal offences, because they might bring about penitence, which is additional to penal sanction (Austin 1873, 112), as well as positive morality oblige persons, but have no precise sanctions. He meant that "laws in figurative sense" denoted so-called laws of nature, perhaps a feigned notion, but contrary to the Hobbes, they were irrelevant to the jurisprudence, because they were not set by a human being and had no sanction to determine human motivation. Subsequently, he remarked that only positive laws became subject matter of jurisprudence.

According to Austin, positive laws are set by both legislature and judge that may incidentally overlap with positive morality, even though such morality may provide a starting point of judge-made law whereof, breadth and purposes of positive laws are ultimately determined by political sovereign (Austin 1873, 256-258). As regards to the rule of law, the Austinian point of view upon constitutional status of judiciary was extremely awkward, since he considered that judiciary occupied a position, just like executive or administrative power under direction of the legislature. By the way, we should realize in our mind that the House of Lords, as a chamber in the Houses of Parliament exercised legislative power, at the same time it was (and still is) the highest tribunal of appeal which could adjudicate claims of unconstitutionality and judicial review. I witnessed many times, some criticisms implied that "Austin's sovereign" was very like an animate human being, as well as a king, queen, or prince, but Austin unequivocally expressed that the parliament was sovereign, thereby the king or queen was bound by the parliament and constitution (Austin 1873, 251-252). Austin did not concern about autonomy of law, contrariwise he considered that all positive laws and judge-made law were either direct legislation of the parliament or a kind of its delegation. He unambiguously said that judge-made law was the expression of legislative will of the parliament. Although, Austin claimed that the parliament was sovereign thereon constitution dictated conducts of monarchs as an act of judiciary which might be unconstitutional, but was not inevitably meant "illegal" (Austin 1873, 278). Therefore, the Austinian concept of unconstitutionality does not squarely denote violation of the law, so we plainly assume that his considerations on constitutionality and unconstitutionality were exclusive matters of judiciary and government, anyhow irrelevant to the laypersons or subjects.

Austin explicitly said that compliance to the legal rules hinged on habitual conduct of human individuals, therefore sanction implemented extra motivation (Austin 1873, 92). Austin might be syncretistic somewhere between utilitarianism and Kantian tradition, therefore, on the one hand, he expected to find subjected human individuals who were moulded according to the utilitarian morality, to whom positive rules was addressed. On the other hand, he tacitly postulated subjected individuals who presumptively assented the moral law of Kant or legislative will of political superior. Apart from that gist of the Kantian moral law was prevalent in his lectures, Austin considered that ethics divided legislation, politics, and political economy under Benthamite influence (Austin 1873, 125, 129; cf., Bentham 1957, 310; Sidgwick 1884, 14). When we dimly glance, Austin was well 
adjusted to political conservatism when he strove for individual subjection to law at the expense of autonomy of judiciary, without rehearsing the liberal discourse on rights, despite liberal precepts were underlying at his jurisprudence.

H. L. A. Hart, the contemporary legal theorist, evinced more salient way to demonstrate a legal positivist perspective on how to express outstanding explanation on autonomy of law to a greater extent other than Austin's politicized perspective. Hart, like Austin, relied on obligatory properties of law, but he centered on "ought" modality instead of external constraint of sanction and habit of obedience, by which he delineated legal rules not as outcome of political power. Instead, he hinged on validity of law as an autonomous domain, free from probable vagaries of political power (Hart 1965, 18 et seq.). Thus, Hart considered autonomy of law in two respects: firstly, even legislation was essential owing to the sources of legal norms where legislator metaphorically seemed a person, but persistence of legislative body must be considered in succession and bounded by constitution; and secondly the Hartian conception of the rule of recognition seems to be achieved to disjoin law from politics and contrary to the Austinian concept of legislation, legal system was designated as a comprehensive sub-system of society instead of extension of politics (Hart 1965, 54-55, 67, 75). Perhaps, those are already implied in natural law theories, but they could not reside in command theory of positivism. I frankly express main difference between the two positivisms that Austinian lore can be conceived with reference to the Kantian legacy, even though some Benthamite impacts are recognisable, whereas Hartian positivism is more likely familiar with the Hume's theory of morals.

The backbone of the Hartian positivism is topography of the legal rules, in which primary rules are full fledged commands that display all aspects of substantive rules from the eye of a lawyer and layperson, whereas secondary rules are mainly addressed to law officials that comprise recognition, change, and adjudication rules to the extent that the latter group generally comprises procedural rules which cannot be solely applied to any breach of law, but only contrive work and change of the former (Hart 1965, 91-94). Additionally, Hart pointed out that the power-conferring rules envisage public or private persons to act binding wills or contracts that assign parties a special capacity to act discretion which plausibly set up proper grounds of ruling for legal dispute concerned (Hart 1965, 35-38). The Hartian depiction of legal rules suitably demonstrates inclusive character of legal system that is not an extension of political power, because the law can accomplish a capacity to restrain tensions between legal and political sub-systems. Regarding the contemporary democracy experience, electoral institutions must be balanced by the legal system, as a non-electoral constraint, especially with due regard to the status of constitutional rules. Perhaps, superfluous reiteration, but I should reassert that the rule of law especially necessitates autonomy of law as a countervailing force on politics. While, Austin regarded constitutional rules as a kind of positive morality, i.e., unsanctioned in practice, Hart did not set apart and he considered them as being backed by the legal system. Finally we can say that the legal system is inclusive anyhow in the Hartian conception of law which does not need contribution or guidance of morals under the course of ordinary events, despite the fact that it has open texture and can be changed in guidance of the rule of recognition when hard cases emerge.

The Hartian positivism does not entangle law with any political itinerary as is assumed by a professional lawyer who aims to preserve established legal order, i.e., status quo by means of depoliticizing normative devices, thereby his outlook is determined by a conative balance between prospectively conflicting parties of individuals and groups in terms of liberalism. Its social effect can take place by means of mental representations of lawyers and laypersons, which are treated under guidance of reasonableness to the extent that 
liberalism is assumedly deep-rooted in dominant ideas and representations. Traditional approaches about the problem were under penumbra of religious doctrine and its extension which rested on the line of rationalism and idealism. As an early proponent, we refer Saint Thomas Aquinas who alleged that all positive laws were deduced by way of practical reasoning (Aquinas 2002, 77-84). When a judge adjudicates a violation according to a legal norm or principle of law, it means that he strenuously makes a logical syllogism between a taken-for-granted proposition (the norm or principle) and a factual proposition, which is assumed as representation of a fact. But it is naïve, the major premise is already disabled because it does not denote a fact, so it is not a proposition, only an "ought" statement (cf., Ayer 1971, 104) or performative, whereas minor premise may be considered as a proposition. ${ }^{5}$ Since John Langshaw Austin's (1975) essay in 1962 and John R. Searle's (1969) contribution, "ought" statements do not denote de facto contents, but have been attributed some meanings by way of social convention, and participants of performative statement unanimously assume it in terms of certain conditions and procedure. Even if we presume a syllogism or inference between norm and fact, those are intuitions in mind according to Fregean's point of view, but the will beneath the performative statement is every time problematic, which brings legal practitioner on interpretation. Normally, legal practice impels lawyers to deduce and syllogize, but in practice it is void. Moreover, argumentation process is a debated area of rival justifications, in which judicial decision takes place through some number of logical inferences, deontic valuations (Von Wright 1951), empirical trial, and error processes according to the content of the case at hand. Furthermore, adjudication is a corporate action to the extent in which some number of associated judges, jurors, appellate court members, and attorneys take part, so more syllogisms instead of a single judge's subsumption would be carried on (Mac Cormick 1978; Raz 1999). Contrary to the hazy expectations, deductive reasoning is not squarely plausible in judicial process; notwithstanding we can only say that there should not be obvious errors in syllogisms or inferences, and that alternate reasons should not be carelessly omitted.

Comparing the different domains of politics and law, we try to set a determining criterion in any constitutional system, which is a manifestation of duly arrangement of both, whereby they are expected as an interplay between normative and factual under binding role of judiciary. Apart from notoriety of his political experience, Carl Schmitt expounded the two reference points on politics that firstly he relied on friend and foe confrontation, and secondly, he focused on capability to proclaim exception (e.g., emergency condition) in definition of sovereignty and on how legitimately to terminate established legal guarantees of society (Schmitt 1996, 25 et seq.; 2005, 5-15). Although Schmitt's point of view is incorrect at least from the two points, firstly he equated sovereignty with politics with disregarding structural space of law and separation of powers in a constitutional government, and secondly he de-contextualized politics with his misinterpretation on other social sub-systems, especially on economics (Schmitt 1996, 23, 37). In effect, politics is a ubiquitous human achievement that engenders conflict among individuals, political groups, and proponents of some social classes for maximizing their interests, but it is not negligible that conflict is not endless in any society, contrariwise it eventually reaches balance thereof and has recourse to law, even if this balance is ephemeral or unstable.

Albeit his fallacies, Schmitt revealed that politics has a peculiar raison d'etre, which takes place in a conflicting environment and is carried on with matter-of-fact logic, partisanship in the milieu of contingencies of struggle, negotiations, and temporary conciliations until the ultimate victory is gained. Any sovereign state cannot endure only in conflicts; therewith status quo is necessarily a ubiquitous equilibrium of political and non-political powers, wherein we assume domain of law amongst non-political powers. It seems that Schmitt had been already conscious of non-political power of the law in a constitutional system when he carelessly 
condemned de-politicalization in bourgeois state, liberalism, and the rule of law. Normally, politics engenders partisanship for interest articulation, but law is impartial, depoliticized, and non-contingent so that it safeguards legitimized interests of disputed parties in the case at stake, thereby the legitimate interests substantially mean legally recognized rights. Initially, the minimal properties of law may be aligned as universality, impartiality, abstractness of norms, and calculability and predictability of outcomes that are corresponded with its depoliticized role; whereby system of positive laws is the main tenet of legal domain. As an outcome, I can frankly express that super-structure of a capitalist society and its constitutional system is due to the power allocation and equilibrium to some extent between political and non-political powers, as is postulated in the separation of powers doctrine. By the same token, Lon Fuller (1969, 33 et seq.) pointed non-political properties of law in his description on indispensable legal principles in The Morality of Law that they are more than overall moral principles, among which he aligned generality of laws, their promulgation, non-retroactivity, clarity, being non-contradictory, ordering only possible condition, constancy, and congruence between action and declared rule. Those are addressed to the lawyers and lawmakers, because to observe them is a prerequisite of any valid legal system in terms of positive laws. In any constitutional system which is stemmed from the rule of law, probable failure onto such principles can be actionable whether or not regarding their "moral" properties. In sum, I express that legal practice needs reasoning, even though its outcomes are unsatisfying, and depolitical power of judiciary in the constitutional system ubiquitously justify its role, which has been culminated in hard cases, stare decisis, or equity law.

Although to research legal positivism in historical context is a tremendous achievement, it is not easy to grasp all its problems in a general appraisal, we can make only some generalizations. I think we can trace two main stages of the legal systems in civilized condition of humanity. The first stage may denote historical civilizations from early urban revolution to capitalist society that coincided with a series of transitions and much of them are encountered in studies on the history of civilization. Jan Assmann (1992), a well-known Egyptologist, brilliantly analyzed that early state formation and high cultures of the Middle East when he interpreted Ancient Egypt, Mesopotamia, and Hebrew cultures, wherein theology formation and canonization of social order formed a patriarchal law which was intertwined with religion and a fundamental shift in memory formation as common results of literary development by means of script, history formation, and founding archives. Assmann named the last one "cold memory," at the expense of "the warm memory" of primitive (i.e., prehistoric) society. It is evident that Assmann's generalizations are not entirely compatible with the Greek and Roman civilizations because of the fact that the two examples remarkably deviate from ancient Sumer and Egypt civilizations with their difference from middle-east colonization of environment and theological development. Anyway, Asmann's point of view designates the typical form of pre-modern (pre-capitalist) legal order, for which there was a conspicuous connection between political domination, legal canon, theology, and dominant morality. In this milieu, religion and obligation to obey law were their congenial properties and this nexus withheld deliberation of human individuals on how positive laws and conception of eternal order in theology were equated one with another.

The second stage may be matched with capitalist social formation from early beginnings to the zenith of competition in free market in mid-nineteenth century and that example is still the starting point for the contemporary liberal lawyers and their debates on law and social order. It is not easy to summarize tremendous number of contingencies which set up capitalist social formation, but we can precisely say that, among others, the three developments took place from legal point of view, which were secularization of society, emergence of 
individual, and market-modeled society. Initially, the secularization aroused in struggles between princes or kings and patriarchal power of the Papacy and they incrementally stirred secularization in politics and law. Indeed, the "human laws" in Summa Theologiae of St. Thomas Aquinas was not incidental when we considered political events in the author's lifetime between 1225 and 1274. On the one hand, 13th century was early formative era of capitalism which was revealed at the emergence of the Italian commercial city-states. On the other hand, another development in Europe that matched with conflict between ecclesiastical and secular rulers and coupled with legal debate between the canonists and the civilians, and that consequently reached the great schism in the church from 1378 to 1417 (Fasolt 1955). St. Thomas Aquinas overtly thwarted the theses of Papal domination on princes and people in his aforementioned book in which he assigned the task of the Church to teach them according to the "true" doctrine (Aquinas 2002, 17-52). By the same token, St. Thomas Aquinas expressed in IaIIae 90 of Summa Theologiae that all laws were addressed by way of practical reasoning which were acknowledged to follow the straightforward line of: (1) definition; (2) proposition; and (3) syllogism or argument (Aquinas 2002, 77-78). Even so, human beings were presumed as incapable of apprehending the eternal law, because it emanated from divine providence and the practical reasoning designated common property of all human beings, and all human laws addressed to rational individuals, which might be apprehended by them. In this context, St. Thomas Aquinas traced human laws that were promulgated by secular ruler (e.g., a king) as positive laws which would prohibit more grievous vices and prescribe only some kind of virtues by means of their letter (Aquinas 2002, 126 et seq.). Additionally we can see that, contrary to the classical Roman law provisions, ius gentium belonged to the positive law in Summa Theologiae together with ius civile, thereon, we see that all practicable laws were reckoned in the human laws (Aquinas 2002, 135).

In fact, the system of positive laws became main topics of legal scholarship while the canonical law was incrementally decaying. Shortly after the works of St. Thomas Aquinas, William of Ockham objected papal power in politics and law and manifestly condemned Pope because he should not have overwhelmed the emperor and kings with duly regarding personage of the Pope in terms of natural equality, despite his exclusive duties and performances which were assigned as services for believers (Ockham 1992, 15, 29, 40). When he referred the principle in so-called Mathew, "Give to Caesar the thing which are Caesar's," he obviously said that the emperor and other secular rulers should legitimately perform their sovereign powers, even if they had been unbelievers. William of Ockham unequivocally condemned Popes thereon; he obliquely asserted that all governmental powers, such as legislative, executive, and judicial, must have unreservedly belonged to the secular rulers. In the same way, he also clearly said that Roman Empire had not been established by God (Ockham 1992, 115), therefore, according to the divine commands, Roman emperors should be obeyed, even though they were unbelievers. It seems that William of Ockham emphasized on the will theory that, on the one hand, he inaugurated it in the inception of imperial power, on the other hand, his legal positivist outlook might be, perhaps equivocally, inherited by the legal positivists of the modern times (Ockham 1992, 127-128). He said that, albeit tyranny should not be legitimized, sovereign power could promulgate human laws, nominate judges and, if the Pope erred, sentence him by trial (Ockham 1992, 99, 138, 156-159). Therefore, as he instanced the king of France, the popes should subject to power of secular princes, their edicts and jurisdiction. The last step is obvious that the reasoning of William of Ockham, per se a substantial revulsion in the contemporaneous discourse on political legitimacy, has reached the degree where his only recourse was territorial state and human (i.e., positive) laws. 
Lastly, I point out Thomas Hobbes who might be considered to be at the last stage in transformation of the pre-modern political power in order to uphold secular monarchy by way of conveying ecclesiastical power from clergy to the hands of political sovereign. I will not reiterate well-known political theory of Hobbes, but I briefly mention his civilian legal point of view. Hobbes started from ius civile in order to ground on the laws of commonwealth, wherefore they were promulgated by sovereign. Hobbes explicated civil laws that they designated right and wrong conducts, and that despite all laws of commonwealth had presumably stemmed from natural law, they might be promulgated as positive laws (Hobbes 1998, 175 et seq.). Owing to aforesaid idea of Hobbes on "positive" conception, this point of view might make indistinct the borderline between positive laws and other types of laws. Thus, Hobbes considered that the law of nature and civil laws can encompass each other, therefore all unwritten laws are included in the law of nature (Hobbes 1998, 177-180). In the same way, Hobbes considered that so-called "positive laws" encompass not only distributive and penal laws, but also "divine positive laws," among which the old law of Old Testament and the new law of New Testament are included (Hobbes 1998, 189-191).

Hobbes unequivocally traced civil laws with reference to the sovereign power, which was personified as Leviathan, really supreme, and being flattered. This characteristic construes right as law, by which he vaguely implies the dyadic relationship between private and public spheres. Hobbes pointed out the dyadic relationships between right and law when he pointed out a common mistake that lex civilis and ius civile were promiscuously used, where the former enunciated [a] "law" and the latter, [the] "right civil" (Hobbes 1998, 192). I am personally convinced of that diversity, but it must be pointed out that he had expressed how "right" meant liberty which had been assigned to us by a civil law, but at the same time it had per se referred to an obligation. In this context Hobbes relies on law of nature for framing rights and freedoms of individual, but, in practice, those are defined and bounded by positive laws. Corollary of this idea, rights of the sovereign Leviathan and rights of a subject were meticulously contrasted, especially when we glance at enumerated lists of the rights of sovereign and the rights of subjects (Hobbes 1998, 115-122, 139-148). These compartments would be matched with the two types of personality, as Hobbes borrowed from Roman law, persona signified disguise or outward appearance instead of natural human individual, as etymology of the word signified in Latin language as masks of actors or actresses in theater (Hobbes 1998, 106-110). Subsequently, we see that Hobbes recognized legally bestowed personality of inanimate things and communities, which are named as legal personalities. Corollary of this idea, Hobbes opened up the conception of legal personality of state that was assumed within duly recognition by way of irrevocable social contract.

The divorce between monarchical power and religious canon was a new stage of history which was a consequence of a tremendous social change and echoed in the cleavage between civilian and canonist lawyers (Stein 2004, 55-61), and it cannot be squarely reduced to philosophical reflection and casuistry. The key problem was radical change in the power system, by which political and depolitical domains were eventually established in a new form of sovereignty that totally engendered liberal society. Regarding to social movements of early modern Europe, in which some convulsions can be enumerated as peasant rebellions, enclosure policy of the Tudor kings, grievances pursuing the true religion debates like Hus or Becket events, and bourgeois revolutions (from Dutch revolution at the end of 16th century up to 1848 tide), liberal political order yielded from those events. Apart from some debates among lawyers and philosophers, liberal government was clung on to constitutional form that resorted to a balance between political and depoliticized countervail power of law which was mostly proxy of economic power. Regarding to the small business substratum of competitive 
capitalism, the countervailing power of law manifested itself by way of the rule of law and protection of individual liberties. From the legal point of view, capitalism ubiquitously transformed the nexus of ancient social order, as had been manifested in well-balanced liberal heyday of modernity, political participation, and legal apparatuses were relatively working in a non-controversial pattern, beforehand the right to vote had been stringently granted only to the propertied classes. In this milieu, we must ponder that subaltern classes were very seriously ousted from politics, even though they partially enjoyed expanded liberties of individual. Liberal politics and the liberal rule of law overlapped with one another, but estrangement of the subaltern classes eventually would destabilize vulnerable balance between the liberal rule of law and night watchman state, especially after they raised their voice for universal suffrage and social equality (Ozcan 2008; 2012).

Positive laws were most important aspect of social order from early beginnings of civilized societies, even if the law was generally in canonical form. Apart from dictatorial inclinations in the certain periods of modernity or in underdeveloped countries which confined politics into a low-level legitimacy, not only positive laws, but also the rule of law manifests an inclusive system of social order in order to undertake legitimate governance in any capitalist society. Daily life of modern society would only be duly administered by means of positive laws, nonetheless political, or administrative discretion must be either entirely non-existent in grievances between both of individuals and government or otherwise unseen. The legal form, which is named as the liberal rule of law, needs a few implacable preconditions: (1) The need for a sovereign state where it would be, as aforesaid, in the form of liberal government, by which public and private spheres are duly diversified or spatialised; (2) Corollary of the previous condition, the form of social relationships must be consequentially redefined according to personality presumption through long-term experience under auspices of lawyers' artifice, whose core idea was the rights and liberties of individual; (3) As is expressed by Locke, life, liberty, and property are indispensable and they are postulates of legality which engender the prevalent conception of the "right." As has been implied in the will of sovereign and freedom of will for individuals, the law is obligatory for all members of legal community, therefore their aggregation is legitimized by protection of the rights of individuals; and (4) Private property right is a crucial problem and as far as I am concerned, all legal scholars of capitalist modernity unanimously upheld property rights in ideologies of law, and they held indispensable in open-ended legal rhetoric or principled under miscellaneous doctrines, such as natural rights, utility, or welfare. Even though this was viable and small property ownership was prevalent, the aforesaid legitimization was seriously undermined after threshold of monopoly capitalism, but ostensibly maintained.

Owing to my aforesaid opinions about how morality and society, they have been disentangled since early stages of capitalist development, legal system pursues same path, but needs a certain level of objectivity of law indispensable in the properties of law. Objectivity of law necessitates its autonomy in social milieu, whatever is accomplished with its impersonal realization and formalness is not only a discursive claim, but also necessitates an accomplishment for social approval. Berger and Luckmann, the two sociologist of knowledge, alleged that objectivity is a kind of sedimentation of inter-individual experience and that it yields with logical coherence somehow accomplishes both of legitimisation of power structures and socialisation of individuals (Berger and Luckmann 1991, 88-109). Beneath the objectification process, there is an underlying reification of certain mental representations as outcome of social experience that comprehends a social practice as likely as "if it were things." The idea is not new, Karl Marx pointed out the aforesaid reification about one hundred years ago in his "commodity fetishism" concept when he wrote that commodity form of products concealed surplus-value exploitation in capitalist mode of production (Marx 1909, 81-96). The point of view must be taken seriously 
and it transmutes labor activity to purchase of work force, because capitalist market magically brands everything (even labor time) as exchange value. Evgeny Pashukanis, the Soviet legal theorist, transferred the idea of Marx to interpretation of semi-autonomous character of the law in capitalist society (Pashukanis 1980, 273-301). Pursuing the commodity form invention of Marx, he considered that the legal form, as a kind of reification, conceals power of bourgeoisie, by which I feel an affinity with my conception on "depolitical power." Furthermore Gramsci sets forth a more elaborated structural approach that super-structure of capitalist society is divisible as state and civil society, as duly, but unstable balance in their totality. He implied that the law is engendered from civil society in its objectified form, which governs the sphere of individuals with safeguarding so-called freedom and impartiality (Gramsci 1992,195-196, 262-263).

The reification conception opened a new way to an institutional theory of law, as Berger and Luckmann expressed that institutions denote objectified form of social practices, including legal domain. The institutional theory of law has a remote history which, the first time, was proposed by Maurice Houriou and other French and German legal scholars, like Esmain, Duguit, or Renner at the early decades of twentieth century. It was deeply concerned to legalization or depoliticization of the state, which assumed objectivity of legal forms in augmenting space of public law (Hauriou 1918; Renner 1949) or its proliferation in collective practice of society. The institutional point of view has congenially a sociological character that is a part of social system approach through social experience. John Searle endeavored to clarify articulation of moral rules and statements by way of institutional expressions, to that end he borrowed Anscombe's distinction between "brute facts" and "institutional facts" (Searle 1969, 50). Brute facts have semantically no meaning, but institutional facts, as speech acts, are considered within a common state of mind, procedure, and a social convention, by which their meanings are depending on the institutionalized systems of society (Searle 1969, 54-71). As above-mentioned, moral ${ }^{6}$ rules and statements are not propositions, but "ought" statements, exhortations, directives, and commands, and the speech-act theory clarifies locutionary, illocutionary, and perlocutionary statements so that they may become meaningful as institutional facts.

The institutional theory of law opened up a new horizon to legal positivism with contribution of sociology or social theory. Institution is already a familiar category to the legal theory where all topography of legal norms and conceptions were institutions which were established in a historical process and articulated according to the social experience, especially under determinative influence of power relations and the mode of production. Neil MacCormick and Ota Weinberger (1992) proposed a very persuasive institutional theory in 1986 that they interpreted legal practices within its surrounding institutional system. Regarding to the consequential argumentation and legal rhetoric, institutional system should be considered in the milieu of legal communication, wherein norms and their use would be treated similar to components of social structure. Normally, our ontological debates on legal norms remind us of a personified lawmaker or a collective author, but the institutional theory engendered a new approach that treated norms as system dependent, like the facts or phenomena which can be explored as outer realities (Weinberger 1992; cf., Morton 1998). The institutional theory prospectively may advance under guidance of system theory, especially with autopoietic theory to the extent that to probe articulation mechanism of legal norms by way of internal communication of law officials and parties of legal disputes, as Luhmann (2004) alleged that system building (i.e., objectification) in law is outcome of an autopoietic communication. 
Lastly, I am able to say that we can apprehend legal system as research subject of legal positivism which works as an outward reality to individuals and objectively present, similar to the other structural phenomena of society. The judges and lawyers are incumbents to carry on it in a depolitical and impartial itinerary, whether they wanted to be positivist or not. Despite the fact that norms and performative statements are crucial problems in their epistemology at any rate, legal systems demand rationality, which is close-knitted with universality, objectivity, and impartiality assumption of law. Rationality is not plainly considered as reasoning, but being capable of communication between internal and peripheral actors or participants of legal system, nevertheless, as Max Weber pointed out, rationality is far-reaching aspect of legal domain whose development we estimate, in both of formal and substantive areas (Weber 1954, 156 et seq.).

\section{Conclusions}

Presuming a triadic relation between morals, ethics and law is a very attractive idea that their conjectural interaction might have secured the correspondence between law, individual and society in a manner plausibly guaranteeing observance of the law. In fact, capitalism had already undermined common customs and morals of society since its early beginnings, when individual, its official persona, steadfastly became free and "rational," therefore ethics can be interpreted in guidance of him either with discourse of pure rational deliberation or emotional experience. Notwithstanding the emergence of free and deliberative individuals, the residual or scant moral domains were fractured with demerit of conflicted interests, especially with class conflict after subaltern class politicization. Therefore, on the one hand ethics and morals seemingly bifurcated, on the other hand, despite some morals remained in market relations, law and morals generally lost their familiarity, thereon morals entangled with interest articulation instead of devotion, solidarity, and supererogation. In this context, positive law became the exclusive recourse for social order, to the extent that it is an inclusive system of society which was embarked on as a depoliticized and unseen power system. The theories on the convergence or concurrence of morals and law are generally depending on a presumption about legally approved morality, not any spontaneous and pure morality, therefore legitimization of law by means of morals is generally a circulus vitiosus, likely to explain something with reference to itself.

\section{Notes}

1. Kant's (1898) oldest book on the moral law is at the beginning of the Kingsmill's edition, despite I got another independent edition which translated by Paton (Kant 1947), but for the sake of easiness, I preferred to cite Kingsmill's translation

2. The practical reason conception must be originated from St. Thomas Aquinas (2002).

3. As regards the chapters on "The Immortality of Soul as a Postulate of Pure Practical Reason" or "The Existence of God as a Postulate of Practical Reason" (Kant 1898, 218-228), I frankly say that Kantian morality might be considered as reassertion of Christian morality, which revealed from Divine providence, as posited by Spinoza (1994, 85 et seq.) in first and fifth chapters of Ethica.

4. Not only morals, but also all structuration of society was engendered by means of communication between individuals which was marked by Lévi-Strauss $(1979,60-61)$ into three modes of communication, i.e., communication of objects, phonemes and women.

5. Hans Kelsen $(1978,195)$ identified law as a taken for granted logical unity which deduced from his presupposed basic norm.

6. Searle preferred concept of "ethical," but I preferred to say "moral," because of my above-mentioned opinion about diversity between morals and ethics. 


\section{Works Cited}

Aquinas, St. Thomas. Political Writings. Ed. and Trans. R. W. Dyson. Cambridge: Cambridge Uni. Press, 2002,

Assmann, Jan. Das kulturelle Gedächtnis: Schrift, Erinnerung und politische Identität in frühen Hochkulturen. Munich: C. H. Beck, 1992. (Turkish translation: Jan Assman. Kultürel Bellek, Eski Yüksek Kültürlerde Yazı, Hatırlama ve Politik Kimlik. Trans. Ayşe Tekin. Istanbul: Ayrınt1, 2001.)

Austin, J. L. How To Do Things With Words. 2nd ed. Oxford: Oxford University Press, 1975.

Austin, John. Lectures on Jurisprudence. 4th ed. Vol. 1. Ed. Robert Campbell. London: John Murray, 1873.

Ayer, A. J. Language, Truth and Logic. Harmondsworth: Penguin, 1971.

Beaumanoir, Philippe de. Cotumes de Beauvaisis. Ed. Am Salmon. Paris: Alphonse Pichard et Fils, 1899.

Bentham, Jeremy. An Introduction to the Principles of Morals and Legislation. Oxford: Clarendon Press, 1957.

Berger, Peter L., and Thomas Luckmann. The Social Construction of Reality. Harmondsworth: Penguin Books, 1991.

Christie, George C. "On the Moral Obligation to Obey the Law.” Duke Law Journal 6 (1990): 1311-36.

Cicero. On Moral Ends. Trans. Raphael Woolf. Cambridge: Cambridge University Press, 2004.

Damren, Samuel C. "Stare Decisis: The Maker of Custom.” New England Law Review 35 (2000):1-21.

Fasolt, Constantin. "Visions of Order in the Canonists and Civilian." Handbook of European History, 1400-1600. Vol. 2, Ed.

Thomas A. Brady, Heiko A. Oberman, and James D. Tracy. Leiden: E. J. Brill, 1955. 31-59.

Fuller, Lon. The Morality of Law. New Haven: Yale Uni. Press, 1969.

Gramsci, Antonio. Selections From Prison Notebooks. Ed. and Trans. Quintin Ohare, and Geoffrey Nowell Smith. 11th. İmp. New York: International Publishers, 1992.

Hart, H. L. A. The Concept of Law. Oxford: Clarendon Press, 1965.

Hauriou, Maurice. “An Interpretation of the Principles of Public Law.” Harvard Law Review 31 (1918): 813-821.

Hobbes, Thomas. Leviathan. Ed. J. C. A. Gaskin. New York: Oxford Uni. Press, 1998,

Hume, David. A Treatise of Human Nature. Ed. L. A. Selby-Brigge. Oxford: Clarendon Press, M DCCC XCVI (1896).

Kant, Immanuel. Critique of Practical Reason. Trans. Thomas Kingsmill Abbott. London: Longman, Green and Co, 1898.

---. Metaphysics of Morals. Trans. Mary Gregor. New York: Cambridge University Press, 1991.

---.The Moral Law, Grundwork. Trans. H. J. Paton. London: Hutchinson's University Library, 1947.

---.The Philosophy of Law: An Exposition of the Fundamental Principles of Jurisprudence. Trans. W. Hastie. Edinburgh: Clark, 1887.

Kelsen, Hans. Pure Theory of Law. Trans. Max Knight. Berkeley L.A.: Uni. of California Press, 1978.

La Vopa, Anthony J. Grace, Talent and Merit. Cambridge: Cambridge University Press, 2002.

Lévi-Strauss, Claude. Structural Anthropology. Vol. 1. Trans. Claire Jacobson, and Brooken Grunffest Schoepf. Middlesex: Penguin, 1979.

Locke, John. Two Treatises of Civil Government. Introduction by William S. Carpenter. London: Everyman's Library, 1966.

Luhmann, Niklas. Law As a Social System. Trans. Klaus A. Ziegert. Ed. Fatima Kastner, Richard Nobles, David Schiff, and Rosamund Ziegert. Introduction by Richard Nobles, and David Schiff. Oxford: Oxford University, 2004.

MacCormick, Neil. Legal Reasoning and Legal Theory. Oxford: Clarendeon Press, 1978.

MacCormick, Neil, and Ota Weinberger. “Introduction.” An Institutional Theory of Law. 2nd imp. Dordrecht: D. Reidel, 1992.1 -30.

MacIntyre, Alasdair. After Virtue. Indianapolis: Uni. of Notre Dame Press, 2007.

Marx, Karl. Capital. Vol. 1. Ed. Friedrich Engels. Chicago: Charles H Kerr and Co, 1909.

McIlwain, Charles Howard. "Magna Carta and Common Law.” Magna Carta Commemoration Essays. Ed. Henry Elliot Malden. London: Royal Historical Society, 1917. 122-179.

Morton, Peter. An Institutional Theory of Law: Keeping Law in Its Place. Oxford: Clarendon Press, 1998.

Ockham, William of. A Short Discourse of Tyrannical Government. Ed. Arthur Stephen McGrade. Trans. John Kilcullen. Cambridge: Cambridge Uni. Press, 1992.

Ozcan, Mehmet Tevfik. "The Rule of Law and Human Virtue." Proceedings of the XXII World Congress of Philosophy 40 (2008): 92-105.

---. "Capitalism and the Rule of Law, The Three Stages of Legal Order in Modern Society." Standing Tall: Hommages a Csaba Varga. Ed. Bjarne Melkevik. Budapest: Pázmány Press, 2012. 305-40. 
Pashukanis, Evgeny Bronislavovich. Selected Writings on Marxism and Law. Ed. Piers Beirne, and Robert Sharlet. Trans. Peter B. Maggs. London: Academic Press, 1980.

Petraziycki, Leon. Law and Morality. Introduction by A Javier Trevino. Trans. H. W. B. New Brunswick: Transaction Publishers, 2011.

Postema, Gerald J.. "Law’s Autonomy and Public Practical Reason.” The Autonomy of Law. Ed. Robert P. George. New York: Oxford University Press, 2005. 79-118.

Raz, Joseph. Practical Ressons and Norms. Oxford: Oxford University Press, 1999.

Renner, Karl. Institutions of Private Law and Their Social Functions. Introduction by O. Kahn-Freund. Trans. Agnes Schwarzchild. London: Routledge and Kegan Paul, 1949.

Sahlins, Marshall D.. Tribesman. Englewood: Prentice-Hall, 1968.

Schmitt, Carl. The Concept of Political. Trans. George Schwab. Chicago: University of Chicago Press, 1996.

---. Political Theology. Trans. George Schwab. Chicago: University of Chicago Press, 2005.

Schwarz, Andreas B.. "John Austin and the German Jurisprudence of His Time." Politica. No. 2. (1934): 178-199.

Scott, S. P.. "Preface" in The Civil Law. Vol. 1. Ed. and Trans. S. P. Scott. Cincinnati: Central Trust Co., 1932. 1-55.

Searle, John R.. Speech Acts. London: Cambridge Uni. Press, 1969.

Sidgwick, Henry. The Method of Ethics. 3rd ed. London: MacMillan and Co., 1884.

Spinoza, Benedict de. A Spinoza Reader. Trans. Edwin Curley. Princeton NJ: Princeton Uni. Press, 1994.

Stein, Peter. Roman Law in European History. Cambridge: Cambridge University Press, 2004.

Stopford, Alice. "The Centralization of Norman Justice under Henry II." Selected Essays in Anglo-American Legal History. Vol.1. Boston: Little, Brown and Co., 1907. 111-38.

Tawney, R. H. The Acquisitive Society. New York: Harcourt, Brace and Co., 1920.

---. Religion and the Rise of Capitalism. New York: Mentor Book, 1963.

Thatcher, Oliver J., and Edgar Holmes McNeal. eds. A Source Book for Mediaeval History. New York: Charles Schriber's Son, 1905.

Thibaut. An Introduction to the Study of Jurisprudence (System des Pandecten Rechts). Trans. Nathaniel Lindley. London: William Maxwell, 1855.

Von Wright, G. H. "Deontic Logic." Mind 60.237 (1951): 1-15.

Weber, Max. On Law in Economy and Society. Ed. Max Rheinstein. New York: Simon and Schuster, 1954.

---. The Protestant Ethic and the Spirit of Capitalism. Trans. Talcott Parsons. Introduction. Anthony Giddens. London and New York: Routledge, 2001.

Weinberger, Ota. “The Norm as Thought and as Reality.” An Institutional Theory of Law. 2nd imp.. Dordrecht: D. Reidel, 1992. $37-43$. 